\title{
Aging and the (Chemical) Senses: Implications for Food Behaviour Amongst Elderly Consumers
}

\author{
Charles Spence $^{1, *(1)}$ and Jozef Youssef ${ }^{2}$ \\ 1 Crossmodal Research Laboratory, Department of Experimental Psychology, University of Oxford, \\ Anna Watts Building, Oxford OX2 6GG, UK \\ 2 Kitchen Theory, Unit 9A Alston Works, London EN5 4EL, UK; jozef@kitchen-theory.com \\ * Correspondence: charles.spence@psy.ox.ac.uk
}

check for updates

Citation: Spence, C.; Youssef, J. Aging and the (Chemical) Senses: Implications for Food Behaviour Amongst Elderly Consumers. Foods 2021, 10, 168. https://doi.org/ 10.3390/foods 10010168

Received: 23 December 2020 Accepted: 10 January 2021 Published: 15 January 2021

Publisher's Note: MDPI stays neutral with regard to jurisdictional clai$\mathrm{ms}$ in published maps and institutional affiliations.

Copyright: (C) 2021 by the authors. Licensee MDPI, Basel, Switzerland. This article is an open access article distributed under the terms and conditions of the Creative Commons Attribution (CC BY) license (https:// creativecommons.org/licenses/by/ $4.0 /)$.
Abstract: The growing aging population are increasingly suffering from the negative health consequences of the age-related decline in their senses, especially their chemical senses. Unfortunately, however, unlike for the higher senses of vision and hearing, there is currently nothing that can be done to bring back the chemical senses once they are lost (or have started their inevitable decline). The evidence suggests that such chemosensory changes can result in a range of maladaptive food behaviours, including the addition of more salt and sugar to food and drink in order to experience the same taste intensity while, at the same time, reducing their overall consumption because food has lost its savour. Here, though, it is also important to stress the importance of the more social aspects of eating and drinking, given the evidence suggesting that a growing number of older individuals are consuming more of their meals alone than ever before. Various solutions have been put forward in order to try to enhance the food experience amongst the elderly, including everything from optimising the product-intrinsic food inputs provided to the remaining functional senses through to a variety of digital interventions. Ultimately, however, the aim has to be to encourage healthier patterns of food consumption amongst this rapidly-growing section of the population by optimising the sensory, nutritional, social, and emotional aspects of eating and drinking. An experimental dinner with the residents of one such home where nostalgic-flavoured healthy ice-creams were served is described.

Keywords: aging; chemical senses; multisensory flavour perception; gustation; olfaction; digital commensality

\section{Introduction}

The chemical senses, namely smell (olfaction), taste (gustation), and the trigeminal sense, just like the higher spatial senses of vision, audition, and touch (e.g., [1-4]) start their inevitable decline as we age (e.g., [5-15]). Unfortunately, however, there are currently no remediation devices, such as glasses and hearing aids, that can be used to make up for the loss of the chemical senses [16,17]. This is especially problematic given a growing aging population [18], with more people than ever before living to an age where impairments to their chemical senses starts to become much more noticeable. To give some sense of the emerging problem, according to the National Institute on Aging, National Institutes of Health [19], the number of those living into their eighties has grown exponentially over the preceding 40 years.

\subsection{Sensory Decline in Aging}

Our sensory and perceptual functions start their inevitable decline at different ages and at very different rates (see [20-22]). For example, while tactile, auditory and visual perceptual abilities show clear signs of decline by the time we reach middle age, taste and smell sensitivity do not show any marked deterioration until we reach 60-70 years of age, whereupon aging takes a greater toll on smell than on taste $[2,15,23-26]$. These age-related 
declines in sensory processing reflect the consequences of both peripheral physical and central neural degeneration (such as the increasing opacity of the lens of the eye, and the general reduction in the population of nerve cells), as well as the cognitive decline associated with a general loss of flexibility of mental processing in older individuals (see also [27-29]). Some commentators have even suggested that this cognitive inflexibility may actually provide older people with the "comfort and security in seeing and hearing events in the accustomed way" ([2], p. 96; see also [30]).

The decline in the sense of smell with aging $[26,31,32]$ is likely to exert a more pronounced detrimental effect on multisensory flavour perception than any loss of taste (gustation), given figures suggesting that as much as $75-95 \%$ of what we think we taste, we actually smell [33]. Here, though, it is important to highlight the potentially important distinction between orthonasal smell (as when we sniff food) and the retronasal release of volatile-rich aromas pulsed out from the back of the nose when we swallow and masticate [34,35]. Interestingly, while most studies of the decline in olfactory sensitivity with aging have assessed orthonasal olfaction, it has been suggested that the findings do not necessarily provide a reliable prediction of retronasal experience, especially when dealing with complex foods [9,36-38]. Research looking specifically at the age-related loss in the sense of taste (gustation) has revealed a decline in sensation for the majority of basic taste qualities [39-41]. That said, there is also some older evidence to suggest that people's sensitivity to specific individual taste qualities may also change differentially across the lifespan. For example, the sensitivity to sweetness is sometimes maintained while the sensitivity to saltiness has been reported to deteriorate significantly (e.g., [42]).

One of the key problems for those hoping to optimise the design of food and drink products for the elderly is that the variability in sensitivity to olfactory stimuli across the population tends to increase as we age [43]. What this means, in practice, is that while some elderly individuals may be functionally anosmic, others may retain a level of olfactory functioning that is not much different from their younger counterparts. Another point to stress here is that, if anything, the decline in chemosensory function in the elderly often appears to be more apparent when assessed with pure tastants/olfactory stimuli than when assessed with real food stimuli (e.g., see $[40,41])$. Here, it would certainly also be interesting to know more about whether or not orthonasal and retronasal olfactory abilities decline at the same rate in the elderly $[9,44]$.

Intriguingly, those who have lost the ability to taste, for example, in the case of herpes zoster oticus in the case of the psychophysicist Pfaffmann (see [45]), report remarkably little loss of taste sensation. Similarly, Brillat-Savarin [46] reported on the case of soldiers whose tongues had been cut out in the Algerian war also reporting little loss of sensation as far as the flavour of food and drink were concerned. By contrast, those of us who have had a head cold know only too well the profound loss of taste that often results when olfactory inputs are not available.

Meanwhile, in a study of nearly 2000 people ranging from 5 to 99 years in age, Doty et al. [24] reported that the ability to identify smells peaked between the ages of 20 and 40 years, and started to decline thereafter. In fact, over half of the 65-80 year olds tested by Doty and his colleagues, and more than three-quarters of those over 80 years of age, exhibited major impairments in olfactory processing, with many exhibiting a clinical deficit in their ability to sense, known as anosmia (see also the National Geographic Smell Survey, [47], for a much larger survey of the effects of age on smell; and [5]). Crucially, recent increases in life expectancy mean that more people than ever before are currently suffering from age-related impairments in their ability to taste and smell. To give some idea of the magnitude of this change in chemosensory perception, it is predicted that by the year 2025 more than a billion people around the world will be over 60 years of age $[18,48]$.

Research directly comparing age-related declines in olfactory and gustatory sensitivity suggests that olfactory losses tend to start earlier and to be more severe than those seen for taste (e.g., [7]). Moreover, it is important to note that the severity and nature of these age-related declines in chemosensory functioning show marked variability across 
individuals, and also vary markedly as a function of the particular measures of olfactory perceptual ability that happen to be used (e.g., [14]). The decline in chemosensory functioning presumably helps to explain why it is that so many elderly individuals complain that food lacks flavour (given that much of the flavour of food actually comes from its smell; [8]). The growing popularity of pungent spices, such as chilli pepper, black pepper, and ginger in food has also been attributed in part to the effects of aging [49,50]. Similarly the provision of a variety of seasonings, such as butter, tomato ketchup, lemon, parsley, mayonnaise, etc., was shown to exert a positive effect on meal enjoyment and food intake in one study conducted in a nursing home [51,52].

\subsection{Decline in Salivary Function with Aging}

Although it is not often mentioned in the literature, it is important to note that saliva also plays a key role in helping us to masticate and swallow food (see [53], for a review). It also plays an important role in our ability to experience the taste and flavour of food too $[54,55]$. Importantly, salivary function has been reported to decline with increasing age and hence this will also interfere with multisensory flavour perception in the elderly (see [56-61]). The effect of aging on the gut should not be forgotten either [62].

\section{Unhealthy Eating Habits in the Elderly}

The declining chemosensory abilities that have been extensively documented in the elderly can all too easily lead to unhealthy eating habits $[63,64]$, as the latter increase their intake of salt and sugar to make up for their inability to taste these ingredients in food at lower concentrations (e.g., [16,65]). According to Stevens, Cain, Demarque, and Ruthruff [66], older individuals may need to add as much as two or three times more salt to perceive the same intensity in a tomato soup as those who are younger. Shockingly, this figure increased to twelve times for those older individuals who were on five or more medications, which turns out to be the majority of them (see also [8]). Given the negative health consequences of the overconsumption of salt (e.g., hypertension), this likely represents a very serious issue, and one that needs to be tackled by those hoping to optimise food delivery amongst the elderly. Note here only that according to observational data from the Framingham study in North America, the lifetime risk of developing hypertension in those who are 55-65 years of age is 90\% [67].

Researchers argue that many of the most serious problems faced by the elderly stem from age-related changes in their sense of smell and to a lesser extent taste, rather than from the age-related declines affecting any of the other senses. This is all the more unfortunate given that many older people claim that eating and drinking represent the last remaining pleasures in their lives [68]. Or, as the famous French gastronome Jean Anthelme BrillatSavarin put it almost two centuries ago that: "The pleasures of the table, belong to all times and all ages, to every country and to every day; they go hand in hand with all our other pleasures, outlast them, and remain to console us for their loss." ([46], p. 14).

The fundamental point here is that the provision of acceptable food needs to be recognised as an important factor determining the quality of life for many older individuals, especially those who find themselves living in care facilities ([69], p. 150; [70]).

\section{Malnutrition-An Increasingly Common Problem Amongst the Elderly}

Many older people, especially those who find themselves in hospital or else in a care home setting, all too often fail to eat sufficiently to maintain their weight (e.g., [71-74]). It is therefore critically important that we introduce strategies to encourage increased consumption of nutritionally-balanced foods and so avoid the malnutrition that is so often reported amongst the elderly (see also [75]). Indeed, the importance of establishing robust solutions for long-term care residents has been highlighted by a number of authors in recent decades (e.g., [76]; see also [77]). Meanwhile, according to another recent report from the National Health Service here in the UK, providing elderly patients with an extra meal a day halved their chances of dying while in hospital [78]. This presumably assumes 
that they eat that meal, and do not return it to the kitchen untouched, as is unfortunately so often the case [73]. One-on-one support with eating at mealtimes has been shown to be especially effective in increasing patients' consumption of food in the hospital setting, but the associated staff costs normally limit the uptake of this kind of solution [79]. The metallic taste that many patients report while undergoing treatment for cancer would also appear to be an effective appetite suppressant (see [80]). While cancer can strike at any age, the risk increases markedly with age [81,82], thus meaning that the problem of metallic taste may be more prevalent amongst this age group.

\section{Enhancing the Sensory Appeal of Food and Drink Amongst the Elderly}

One route to increasing the sensory/perceptual interest of food and drink amongst older populations is to enhance the stimulation provided by the remaining functional senses $[83,84]$. It has, for example, been suggested that increasing the trigeminal input by incorporating more pepper pungency, heat from chili, and ginger, etc., may help to prevent foods from becoming too bland as an individual's gustatory and olfactory function declines ([49]; though see also [85]; and [86], on the effects of interactions between texture and trigeminal stimulus in a liquid food system on the preferences of elderly consumers). That said, the evidence to date demonstrating increased consumption of taste/flavourenhanced foods amongst the elderly is mixed (see [87], for a review of research to date).

When thinking about how to enhance the design of food and drink experiences amongst the elderly, it is important to note that much of our multisensory flavour experience is determined by our flavour expectations that are built on the basis of associative learning as a result of our prior food experiences. The latter tend to be set by sight, orthonasal smell (sniffing), and, on occasion, sound (think here only of the sizzle of the steak on the hot plate, or the ding of the microwave; [88]) and touch cues-as we feel the softness of the fruit, or the heat emanating from the outer surface of our coffee cup (e.g., [89]). It has been suggested that very often, we live in the world of our flavour expectations, only occasionally checking on the taste of what we are actually consuming (see $[90,91]$, for reviews). Should the taste experience be pretty much as we expected, then we largely live in the world of our flavour expectations. If, however, there is too much of a divergence between expectations and experience, then this may very well lead to a negatively-valenced disconfirmation of expectation response [92,93]. At the same time, however, it is also important to recognize how mental imagery sometimes help to fill in the gaps in our perception of what we expect to taste and smell (see [94,95]). The key point here though is that the visual attributes of those food products designed specifically for the elderly should not be neglected. That is, it is not enough to simply think about flavour enhancement as the only solution to get elderly individuals to eat more/better [87].

It has long been suggested that meals should be made more colourful and sonically interesting for elderly and hospitalized individuals (e.g., $[79,96])$. Further, beyond enhancing the multisensory perception of the food itself, one should not neglect the importance of the colour of the plateware on which it is served (see [97] for a review of the impact of plateware colour on taste and consumption). It has been reported that some older individuals may struggle to distinguish the food from the plate visually, especially when pallid white institutional foods are served against the background of the ubiquitous large round white American plate. Interesting here, therefore, is research showing that simply by switching to high-contrast coloured (e.g., red or blue) plateware and glassware, a dramatic increase in the consumption of food can be achieved, at least in the short term, amongst older patients and care home residents (e.g., [98-102]). Thinking more carefully about the presentation of the food can also help to encourage greater consumption amongst the elderly [103].

Many older individuals, including those who have lost their teeth, are often fed pureed meals as they can find it hard to deal with solid foods [104]. Unfortunately, however, such texturally monotonous foods have lost most of their sensorial interest and hence may result in undernutrition. What is more, the absence of textural cues make it much harder for 
people to identify vegetables too (see [105]). Note here also how many elderly people suffer from a more general difficulty in identifying foods [106]. This is potentially important because people are less likely to consume those foods that they struggle to identify.

Japanese researchers have developed a headset that older people in this situation can wear that presents mastication-like sounds elicited by jaw movements $[107,108]$. It has even been suggested that different sounds might be used to represent different food textures, thus providing an additional sensory cue. Preliminary findings suggest that this might provide an effective means of adding some sonic interest to mealtimes for such individuals, it remains to be seen whether there will be widespread uptake of such high-tech solutions, especially amongst elderly and hospitalized individuals.

\section{Ice-Cream as an Effective Vehicle for Nutrient Delivery in the Elderly}

Ice-cream is often noted as being a popular food amongst many older individuals (e.g., $[109,110])$. Indeed, its unique sensory properties have been highlighted as one of the reasons why so many people find that they still have space for this highly-desirable food even when they are otherwise full at the end of the meal ([111]; see also [112,113]). It may be the case that in some older individuals, the oral-somatosensory cues that are provided by the cold temperature of the ice-cream, as well as perhaps the fatty/creamy mouthfeel characteristics help to provide agreeable sensory stimulation from food in those who may otherwise be suffering from marked olfactory loss or else may even be functionally anosmic (e.g., [47]).

Working with this idea, and against the common conception of ice-cream as an unhealthy (and possibly childish/necessarily indulgent) food, chef Jozef Youssef of Kitchen Theory [114] created a series of ice-creams using a range of healthier ingredients (including pureed vegetables and meal replacement powders such as Huel; $[110,115])$. Furthermore, by using a Pacojet machine to make the ice-cream, it was possible to deliver a deliciouslysmooth texture without the necessity of adding cream. Unfortunately, however, the high price of the latter machines (c. $£ 5000$ for a new model) will likely limit the uptake of this item of modernist culinary technology by most of those providing food for the elderly. The intervention of chefs and neuroscientists to help recover pleasure lost due to sensory loss was also investigated by the Roca Brothers in Spain in 2019 (see [116,117], for a couple of press reports).

While the concept of savoury ice-creams is currently unfamiliar to many Western consumers, they are nevertheless popular in Japan, as well as in the context of many modernist restaurants around the world [118-120]). What is more, savoury ice-creams were once popular in Europe and presumably beyond during the 18th and 19th centuries (e.g., see [121,122]). Appropriately-designed (i.e., nutritionally-balanced) ice-creams may therefore provide an excellent vehicle for the delivery of protein and other elements necessary for a balanced diet in elderly populations who might otherwise be suffering from poor nutrition [123-126]; see also [127,128]). Here, it is worth noting that much the same approach to nutritionally-enhanced ice-cream has also been proposed previously in the case of cancer patients [129]. That said, when introducing novel ice-cream flavours, one has to be careful not to trigger a negatively-valenced 'disconfirmation of expectation' response amongst consumers, elderly or otherwise, who may initially be unfamiliar with such savoury flavours in the context of ice-cream ([130]; see also [92,131]).

Chef Jozef Youssef and his team created a range of savoury ice-creams with various flavours chosen to elicit positive nostalgia amongst older individuals. Given the UK base for this particular intervention, the meal incorporated Heinz cream of tomato soup, prawn cocktail, and bone marrow ice cream flavours (see Figure 1 for the menu from the event). These dishes were served in the context of a multisensory environment that was itself designed to trigger positive nostalgia. For example, traditional visual designs were projected onto the dining table along with retro food labels matching the flavour of the dish the aged diners, and their carers, were currently eating using projection mapping (see Figure 2). Meanwhile, Vera Lynn, one of the most popular vocalists during the war 
years, and such-like was presented over the loudspeakers. Several recent studies have demonstrated that ambient soundscapes influence both the sensory-discriminative and hedonic experience of ice-cream and gelati [132-136]. Although no quantitative data were obtained, the qualitative reports of the various residents and supporters of the Denville Hall residential home for aged actors who supported this particular culinary exercise were, on the whole, very positive [137]. Indeed, the authors hope to collect quantitative data to support the approach outlined here (namely using healthy ice-cream as a vehicle to enhance food consumption behaviours amongst the elderly) in the near future. Until such time, however, the findings reported here should be treated as merely anecdotal.

\title{
Denville Hall Menu
}

\author{
Heinz Tomato Soup
}

Heinz tomato soup ice cream, parmesan crisp, olive oil sand, basil oil, crystal bread

Prawn Cocktail

Marie-Rose ice cream, baby gem lettuce, guacamole, lime \& onion pearls, grilled prawns

\section{Steak Tartar}

Bone marrow ice cream, beef tartare, fuille de brick cone

\section{Duck Ala Orange}

Orange and citrus ice cream, grilled duck breast, turned potatoes, duck jus

\author{
Knickerbocker glory \\ Huel (meal replacement) ice cream, red berry coulis, fresh raspberry, rose and pistachio tuille, rose cream
}

Figure 1. The menu created especially for the nostalgic flavours ice-cream-focused dining concept created for Denville Hall.

\subsection{Music and Soundscapes to Enhance Meal Times Amongst Agitated Seniors}

Another relatively-simple low-cost intervention to enhance food behaviour at mealtimes is to use music, or ambient soundscapes, to help relax those individuals who might otherwise be too agitated to eat. This is apparently a common problem amongst many psychiatric patients as well as a growing number of those older individuals who are suffering from Alzheimers/dementia (e.g., [69,138-140]). Intriguingly, back in the 1970s, a number of psychiatric hospitals in North American would apparently play 'Sea gulls ... Music for rest and relaxation' [141] for just this reason [142].

\subsection{Hunger and Forgetting to Eat}

Research conducted with individuals suffering from amnesia suggests that it is external cues that often trigger the initiation of meal consumption in the absence of awareness /memory of the meals that may just have been consumed [143]. At the same time, however, many of those older individuals living alone may simply forget to eat [144], because they lack the robust external (or exogenous) hunger cues, such as the kitchen aromas of food cooking that may play an important part in encouraging the rest of us that it is time to eat [145]. 

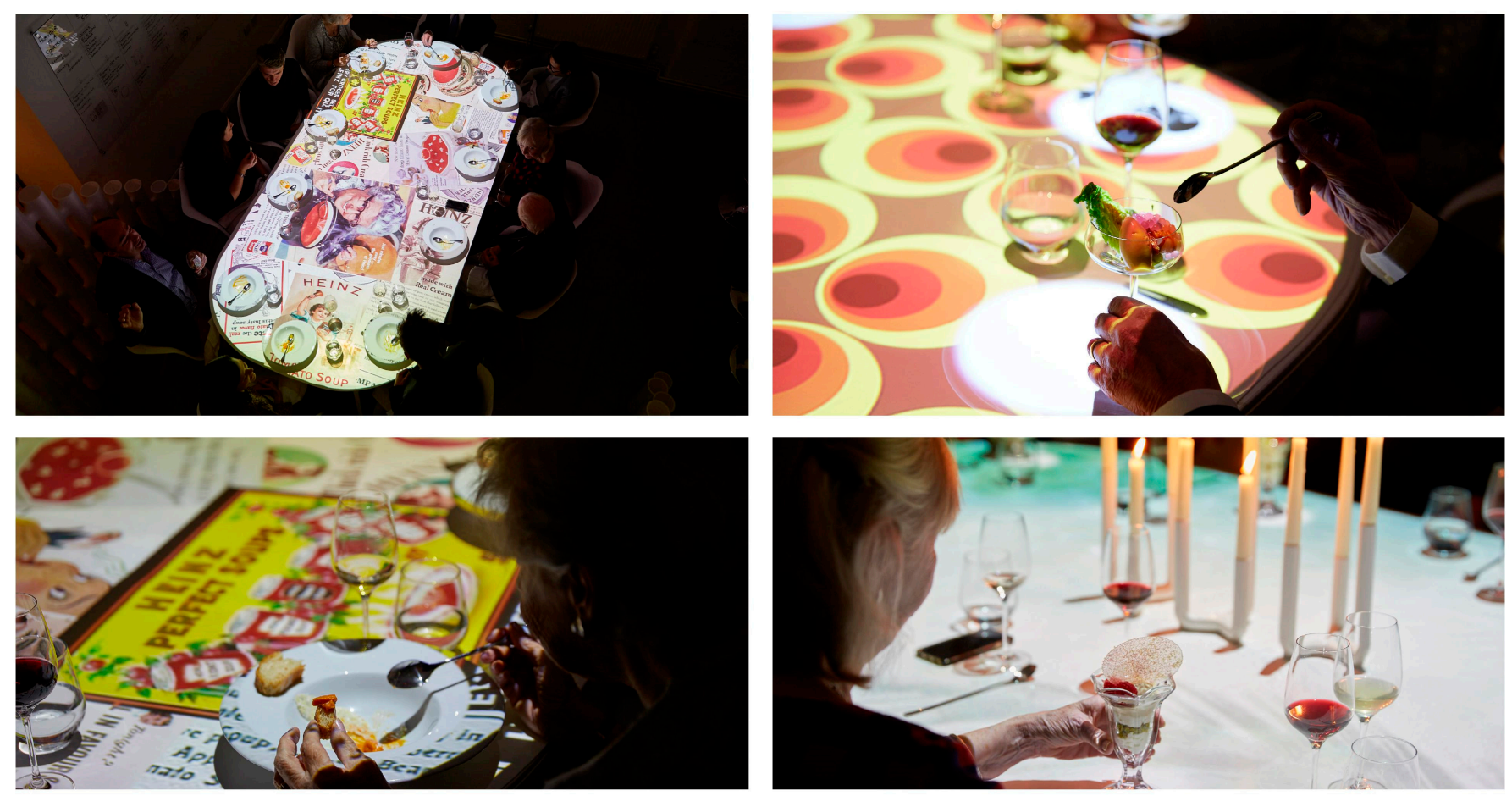

Figure 2. Still images from the Denville Hall dining concept.

In order to try and address the latter problem, Prof. Spence was involved as a consultant in a project a few years ago designed to try and help older individuals, specifically early-stage Alzheimers/dementia patients who might otherwise need to be hospitalized due to undernutrition [146], to retain their independence living at home for a little longer. The idea behind the 'Ode', as it is called, was to release familiar meal time-specific and culturally / age group-appropriate ambient food scents into the home three times a day. The hope was that this might help those who might otherwise forget to eat, to eat. The results of a small study suggested the efficacy of this award-winning plug-in food scent alarm clock device.

The six food aromas developed for the launch included fresh orange juice, cherry Bakewell tart, homemade curry, pink grapefruit, beef casserole, and Black Forest gateau. They were specifically chosen to be representative of food aromas that were likely to be familiar to those in the target age group (though see also [147]). The results of a smallscale 10-week pilot study involving fifty people with dementia, along with their families, revealed that more than half of those who used the device ended up maintaining their weight, or else showing a slight increase, as compared to an expected decline in weight that is so often seen in this group (e.g., $[148,149])$.

\section{Age-Related Decline in Multisensory Integration and Attention}

Flavour is undoubtedly one of the most multisensory of our everyday experiences [150], potentially engaging each and every one of our senses. Hence, over and above any loss of sensitivity in the individual senses that either help to set our flavour expectations, or else contribute directly to our flavour experiences, one might also ask what role, if any, a more central loss of multisensory integration, or information-processing abilities [151,152], might have for food perception/behaviour amongst the elderly. While there has been little research directly targeting this question with respect to the chemical senses, one can find a multitude or answers in the case of the higher spatial senses [153].

For example, Laurienti, Burdette, Maldjian, and Wallace [154] have argued that multisensory integration may actually become more important as we age. They suggest that multisensory integration can, in some sense at least, help to make up for the loss of sensitivity and responsiveness of the individual senses as they start their inevitable decline 
(see also [155]). In their study, Laurienti and colleagues had groups of younger and older participants make speeded detection responses to a random sequence of auditory, visual, and audiovisual target stimuli. While unisensory response latencies were shown to slow with increasing age, multisensory RTs were similarly fast in both age groups. At the same time, however, other researchers have argued that the ability to integrate multisensory cues declines with increasing age (see also $[156,157])$. In particular, the increased risk of falling that has been documented amongst the elderly has been put down, at least in part, to a failure to appropriately integrate vestibular and visual cues [158].

The authors are not, however, aware of any research that has specifically addressed the question of whether there is any central impairment affecting the multisensory integration of the flavour senses (namely, retronasal olfaction, gustation, and possibly also trigeminal inputs) with advancing years. Here, it is worth stressing that it is not only the neural sites of multisensory integration that differ between the chemosensory and the spatial senses, but also the very nature of the rules governing that integration (see [159], for a review). So, for example, spatial co-location, and attention have been reported to play more of a modulatory role over the integration of auditory, visual, and tactile stimuli than would appear to be the case for the integration of the flavour senses.

Visual (colour) cues, in particular, exert a significant modulatory effect over the sensory-discriminative and hedonic aspects of tasting (see [160,161], for reviews). The visual dominance over taste/flavour perception as well as the central importance of visual cues for driving our food selection behaviours both need to be recognised (see [162]). Hence, one might consider whether the presentation of more brightly-coloured foods/dishes could be used to help stimulate the appetite amongst the elderly ([16]; though see also [163], on the changing patterns of sensory dominance with aging). Note here also how the presentation of a visually-stimulating array of produce colours also fits with contemporary nutritional guidelines [164,165].

Attention plays a key role in both the phenomenon of oral referral [166-168] and multisensory flavour perception more generally [169]. Furthermore, in younger people, the research clearly shows that increasing the perceptual load of a visual task lowers taste/flavour perception ([170]; see also [171]). Hence, one danger might be that the loss of flexibility of attentional allocation/switching, in the elderly [172] might mean that the TV dinner has an even more detrimental effect on the perception of food consumption-related sensory cues than on the rest of us [79].

\section{Dining as a Fundamentally Social Activity}

However, over and above any perceptual decline, a large part of the poor food consumption behaviours that have been evidenced in older populations are likely to result, at least in part, from the increasingly isolated living that many older people face, and the consequent lack of social interaction that have been documented amongst older age groups in many countries [79]. To give some sense of the problem in relation to food consumption, in Japan, where people live longer than in most other places, it has been estimated that $24 \%$ of pensioners eat the majority of their meals alone [173]. Importantly, here in the UK, eating meals alone has recently been reported to be the biggest lifestyle cause of unhappiness [174,175].

Recognizing this growing social issue, there is an emerging interest in the field of digital commensality, with a number of researchers trying to bring back the enjoyment of eating by means of digital technologies [176]. While acknowledging the lack of familiarity with contemporary digital technologies amongst many in this age group currently, there has nevertheless been widespread interest in the possibility of using robotic dining assistants to interact with elderly patients, simultaneously monitoring their consumption, and ideally nudging them toward healthier patterns of food consumption. Assisted eating at mealtimes in hospitals also helps here, though, as has already been mention, the cost implications cannot be ignored. This kind of approach recognizes the fact that both physiological and psychological factors play an important role in controlling eating in later life [177]. Of 
course, the social solutions in this space need not be digital, with other commentators advocating for lunch clubs [178]. Of perhaps more widespread relevance, given the rapid rise of at home food delivery services $[79,179]$, there seems to be an unrecognized opportunity amongst the larger providers of food direct to the home (be it take-away or ready-made meals, or even meal kits, from the likes of Deliveroo, Uber Eats, or Blue Apron) to connect those individuals who may be living, (cooking) and eating alone over the internet with other like-minded individuals who find themselves in the same position [176]. There is also scope to enhance the provision of meals for one, too [180,181].

\section{Conclusions}

A wide body of evidence now points toward the conclusion that the rapidly-growing aging population are engaging in a variety of unhealthy eating behaviours. On the one hand, this takes the form of adding excessive amounts of sugar and salt to taste [66], while, at the same time, not eating enough to maintain a healthy weight. Indeed, clinical malnutrition is not uncommon amongst hospitalised elderly individuals, not to mention those living in care homes $[71,72,75]$. While sensory decline, specifically amongst the chemical senses, is undoubtedly partly to blame, the absence of social interaction is also likely to be a core part of the problem [176]. Indeed, one of the key challenges for the future is how to deal with the sensory underload so often experienced by those of advanced years [182], many of whom are living alone and eating alone far more often than they would like. Optimizing food design to stimulate the remaining functional senses (e.g., $[73,96,183,184]$ and harnessing various digital technologies to increase the opportunity for distributed social interaction at mealtimes (and beyond) are all likely going to help manage the situation in the years ahead [176]. Looking to the future, it will likely become increasingly important to consider the changing role of the senses in food choice and food intake across the lifespan [87]. Furthermore, the idea of transgenerational design will likely become increasingly important too $[149,185,186]$, especially given the increasing value of the silver dollar $[187,188]$. The importance of marketing foods effectively to this growing demographic should not be underestimated either [189].

As stressed in this review, one promising vehicle for the delivery of nutritional requirements in at least some elderly individuals may be nutritionally-enhanced ice-creams (see [110]; see also [190]). Such foods optimise food-related stimulation of the remaining functional senses, though the possibility of 'disconfirmation of expectation' given the novelty of such unusual formulations/flavours needs to be carefully thought through [130]. Although there is as yet limited research into this approach, the preliminary evidence at least looks promising [110]. Ultimately, it is only by optimizing the sensory, social, nutritional, and emotional aspects of food and eating design that we will be able to provide a satisfactory food environment in the years ahead.

Further, given the many reports of chemosensory loss constituting one of the most common symptoms of COVID-19 [191,192], a loss that has been reported to affect not only smell and taste, but also the trigeminal sense [193], one might wonder to what extent some of the sensory strategies outlined here to deal with the sensory losses experienced by the elderly might be relevant to providing enhanced food experiences for the worryingly large number of those suffering from long COVID. Indeed, according to the results of the latest report, approximately one-third of patients suffering from long COVID reported impaired chemosensory function three months after infection [194].

Author Contributions: J.Y. and his team at Kitchen Theory developed the dining concept and recipes that were incorporated in the menu. C.S. wrote the literature review and integrated comments from J.Y. in revision. All authors have read and agreed to the published version of the manuscript.

Funding: This research received no external funding.

Data Availability Statement: There is no data to share, though chef J.Y. woud be happy to share the recipes on request. 
Acknowledgments: We would like to thank Kate Wilson and Lalla Ward of Denville Hall for helping to organize the dining event, as well as the support staff and residents who attended the dining event and provided their informal feedback.

Conflicts of Interest: The authors declare no conflict of interest.

\section{References}

1. Colavita, F.B. Sensory Changes in the Elderly; Thomas: Springfield, IL, USA, 1978.

2. Corso, J.F. Sensory processes and age effects in normal adults. J. Gerontol. 1971, 26, 90-105. [CrossRef] [PubMed]

3. Havlik, R. Aging in the eighties, impaired senses for sound and light in persons age 65 years and over. Adv. Data Rep. 1986, 125, $1-7$.

4. Hume, A.L.; Cant, B.R.; Shaw, N.A.; Cowan, J.C. Central somatosensory conduction time from 10 to 79 years. Electroencephalogr. Clin. Neurophysiol. 1982, 54, 49-54. [CrossRef]

5. Cain, W.S.; Stevens, J.C. Uniformity of olfactory loss in aging. Ann. N. Y. Acad. Sci. 1989, 561, 29-38. [CrossRef] [PubMed]

6. Cowart, B.J. Development of taste perception in humans: Sensitivity and preference throughout the life span. Psychol. Bull. 1981, 90, 43-73. [CrossRef] [PubMed]

7. Cowart, B.J. Relationships between taste and smell across the adult life span. Ann. N. Y. Acad. Sci. 1989, 561, 39-55. [CrossRef] [PubMed]

8. Doty, R.L. Influence of age and age-related diseases on olfactory function. Ann. N. Y. Acad. Sci. 1989, 561, 76-86. [CrossRef] [PubMed]

9. Koskinen, S.; Tuorila, H. Performance on an odor detection and identification test as a predictor of ortho- and retronasal odor intensity ratings in the young and elderly. Food Qual. Prefer. 2005, 16, 383-392. [CrossRef]

10. Mobley, A.S.; Rodriques-Gil, D.J.; Imamura, F.; Greer, C.A. Aging in the olfactory system. Trends Neurosci. 2014, 37, 77-84. [CrossRef]

11. Murphy, C.; Schuberts, C.R.; Cruickshanks, K.J.; Klein, B.E.K.; Klein, R.; Nondahl, D.M. Prevalence of olfactory impairment in older adults. J. Am. Med. Assoc. 2002, 288, 2307-2312. [CrossRef]

12. Nusbaum, N.J. Aging and sensory senescence. South. Med. J. 1999, 92, 267-275. [CrossRef] [PubMed]

13. Stevens, J.C.; Dadarwala, A.D. Variability of olfactory threshold and its role in assessment of aging. Percept. Psychophys. 1993, 54, 296-302. [CrossRef] [PubMed]

14. Weiffenbach, J.M. Assessment of chemosensory functioning in aging: Subjective and objective procedures. Ann. N. Y. Acad. Sci. 1989, 561, 56-64. [CrossRef] [PubMed]

15. Weiffenbach, J.M. Chemical senses in aging. In Smell and Taste in Health and Disease; Getchell, T.V., Doty, R.L., Bartoshuk, L.M., Snow, J.B., Eds.; Raven Press: New York, NY, USA, 1991; pp. 369-378.

16. Schiffman, S.S.; Graham, B.G. Taste and smell perception affect appetite and immunity in the elderly. Eur. J. Clin. Nutr. 2000, 54 (Suppl. 3), S54-S63. [CrossRef] [PubMed]

17. Spence, C. The skin as a medium for sensory substitution. Multisens. Res. 2014, 27, 293-312. [CrossRef]

18. U.S. Senate Special Committee on Aging. Aging America, Trends and Projections; US Senate Special Committee on Aging (in association with the American Association of Retired Persons, the Federal Council on the Aging, and the Administration on Aging): Washington, DC, USA, 1991.

19. National Institute on Aging; National Institutes of Health. Global Health and Aging; NIH Publication no. 11-7737; World Health Organization: Washington, DC, USA, 2011.

20. Axelrod, S. Cognitive tasks in several modalities. In Processes of Aging; Williams, R.H., Tibbitts, C., Donahue, W., Eds.; Atherton Press: New York, NY, USA, 1963; Volume 1, pp. 132-145.

21. Baker, M.A. Sensory functioning. In Sex Differences in Human Performance; Baker, M.A., Ed.; John Wiley \& Sons: West Sussex, UK, 1987; pp. 5-36.

22. Gadkaree, S.K.; Sun, D.Q.; Li, C.; Lin, F.R.; Ferrucci, L.; Simonsick, E.M.; Agrawal, Y. Does sensory function decline independently or concomitantly with age? Data from the Baltimore Longitudinal Study of Aging. J. Aging Res. 2016, 2016, 1865038. [CrossRef]

23. Boyce, J.M.; Shone, G.R. Effects of ageing on smell and taste. Postgrad. Med. J. 2006, 82, 239-241. [CrossRef]

24. Doty, R.L.; Shaman, P.; Applebaum, S.L.; Giberson, R.; Siksorski, L.; Rosenberg, L. Smell identification ability: Changes with age. Science 1984, 226, 1441-1442. [CrossRef]

25. Hoffman, H.J.; Cruickshanks, K.J.; Davis, B. Perspectives on population-based epidemiological studies of olfactory and taste impairment. Ann. N. Y. Acad. Sci. 2009, 1170, 514-530. [CrossRef]

26. Kaneda, H.; Maeshima, K.; Goto, N.; Kobayakawa, T.; Ayabe-Kanamura, S.; Saito, S. Decline in taste and odor discrimination abilities with age, and relationship between gustation and olfaction. Chem. Senses 2000, 25, 331-337. [CrossRef]

27. Cain, W.S. Educating your nose. Psychol. Today 1981, 7, 48-56.

28. Cavazzana, A.; Röhrborn, A.; Garthus-Niegel, S.; Larsson, M.; Hummel, T.; Croy, I. Sensory-specific impairment among older people. An investigation using both sensory thresholds and subjective measures across the five senses. PLOS ONE 2018, 13, e0202969. [CrossRef] [PubMed] 
29. Correia, C.; Lopez, K.J.; Wroblewski, K.E.; Huisingh-Scheetz, M.; Kern, D.W.; Chen, R.C.; Schumm, L.P.; Dale, W.; McClintock, M.K.; Pinto, J.M. Global sensory impairment in older adults in the United States. J. Am. Geriatr. Soc. 2016, 64, 306-313. [CrossRef] [PubMed]

30. Weiffenbach, J.M. Taste and smell perception in aging. Gerodontology 1984, 3, 137-146. [CrossRef] [PubMed]

31. Bartoshuk, L.M.; Rifkin, B.; Marks, L.E.; Bars, P. Taste and aging. J. Gerontol. 1986, 41, 51-57. [CrossRef] [PubMed]

32. Stevens, J.C.; Bartoshuk, L.M.; Cain, W.S. Chemical senses and aging: Taste versus smell. Chem. Senses 1984, 9, 167-179. [CrossRef]

33. Spence, C. Just how much of what we taste derives from the sense of smell? Flavour 2015, 4, 30. [CrossRef]

34. Ni, R.; Michalski, M.H.; Brown, E.; Doan, N.; Zinter, J.; Ouellette, N.T.; Shepherd, G.M. Optimal directional volatile transport in retronasal olfaction. Proc. Natl. Acad. Sci. USA 2015, 112, 14700-14704. [CrossRef]

35. Rozin, P. "Taste-smell confusions" and the duality of the olfactory sense. Percept. Psychophys. 1982, 31, 397-401. [CrossRef]

36. Duffy, V.B.; Backstrand, J.R.; Ferris, A.M. Olfactory dysfunction and related nutritional risk in free-living elderly women. J. Am. Diet. Assoc. 1995, 95, 879-884. [CrossRef]

37. Duffy, V.B.; Cain, W.S.; Ferris, A.M. Measurement of sensitivity to olfactory flavour: Application in a study of aging and dentures. Chem. Senses 1999, 24, 671-677. [CrossRef] [PubMed]

38. Koskinen, S.; Vento, S.; Malmberg, H.; Tuorila, H. Correspondence between three olfactory tests and suprathreshold odor intensity ratings. Acta Oto-Laryngol. 2004, 124, 1072-1077. [CrossRef] [PubMed]

39. Methven, L.; Allen, V.J.; Withers, C.A.; Gosney, M.A. Ageing and taste. Proc. Nutr. Soc. 2012, 71, 556-565. [CrossRef] [PubMed]

40. Mingioni, M.; Mehinagic, E.; Siucinska, K.; Konopacka, D.; Artigas, G.; Symoneaux, R. Sweet and sour discrimination abilities of elderly people compared to those of young adults in apple puree. Food Qual. Prefer. 2017, 59, 59-67. [CrossRef]

41. Mojet, J.; Heidema, J.; Christ-Hazelhof, E. Taste perception with age: Generic or specific losses in supra-threshold intensities of five taste qualities? Chem. Senses 2003, 28, 397-413. [CrossRef]

42. Bartoshuk, L.M. Taste: Robust across the age span? Ann. N. Y. Acad. Sci. 1989, 561, 65-75. [CrossRef]

43. Sulmont-Rossé, C.; Maitre, I.; Amand, M.; Symoneaux, R.; Van Wymelbeke, V.; Caumon, E. Evidence for different patterns of chemosensory alterations in the elderly population: Impact of age versus dependency. Chem. Senses 2015, 40, 153-164. [CrossRef]

44. Flaherty, T.J.; Lim, J. Individual differences in retronasal odor responsiveness: Effects of aging and concurrent taste. Chemosens. Percept. 2017, 10, 91-103. [CrossRef]

45. Pfaffmann, C.; Bartoshuk, L.M. Taste loss due to herpes zoster oticus: An update after 19 months. Chem. Senses 1990, 15, 657-658.

46. Brillat-Savarin, J.A. Physiologie Du Goût. In The Philosopher in the Kitchen/The Physiology of Taste; Nimmo \& Bain: London, UK, 1835.

47. Wysocki, C.J.; Gilbert, A.N. National geographic smell survey: Effects of age are heterogenous. Ann. N. Y. Acad. Sci. 1989, 561, 12-28. [CrossRef]

48. Stevens, J.C. Food quality report from noninstitutionalized aged. Ann. N. Y. Acad. Sci. 1989, 561, 87-93. [CrossRef] [PubMed]

49. Lawless, H. Pepper potency and the forgotten flavor sense. Food Technol. 1989, 11, 57-58.

50. Ferris, A.M.; Schlitzer, J.L.; Scheirberl, M.J. Nutrition and taste and smell deficits: A risk factor or an adjustment. In Clinical Measurement of Taste and Smell; Meiselman, H.L., Rivlin, R.S., Eds.; Collamore Press: Lexington, MA, USA, 1986; pp. 264-278.

51. Divert, C.; Laghmaoui, R.; Crema, C.; Issanchou, S.; Van Wymelbeke, V.; Sulmont-Rosse, C. Improving meal context in nursing homes. Impact of four strategies on food intake and meal pleasure. Appetite 2015, 84, 139-147. [CrossRef] [PubMed]

52. Appleton, K.M. Increases in energy, protein and fat intake following the addition of sauce to an older person's meal. Appetite 2009, 52, 161-165. [CrossRef] [PubMed]

53. Spence, C. Mouth-watering: The influence of environmental and cognitive factors on salivation and gustatory/flavour perception. J. Texture Stud. 2011, 42, 157-171. [CrossRef]

54. Canon, F.; Neiers, F.; Guichard, E. Saliva and flavor perception: Perspectives. J. Agric. Food Chem. 2018, 66, 7873-7879. [CrossRef] [PubMed]

55. Muñoz-González, C.; Feron, G.; Canon, F. Main effects of human saliva on flavour perception and the potential contribution to food consumption. Proc. Nutr. Soc. 2018, 77, 423-431. [CrossRef]

56. Chauncey, H.H.; Shannon, I.L.; Feller, R.P. Effect of oral and nasal chemoreception on parotid gland secretion. In Secretory Mechanisms of Salivary Glandsl; Schneyer, L.H., Schneyer, C.A., Eds.; Academic Press: New York, NY, USA, 1967 ; pp. $351-364$.

57. Percival, R.S.; Challacombe, S.J.; Marsh, P.D. Flow rates of resting whole and stimulated parotid saliva in relation to age and gender. J. Dent. Res. 1994, 73, 1416-1420. [CrossRef] [PubMed]

58. Scott, J. Age, sex and contralateral differences in the volumes of human submandibular salivary glands. Arch. Oral Biol. 1975, 20, 885-887. [CrossRef]

59. Vandenberghe-Descamps, M.; Labouré, H.; Prot, A.; Septier, C.; Tournier, C.; Feron, G. Salivary flow decreases in healthy elderly people independently of dental status and drug intake. J. Texture Stud. 2016, 47, 353-360. [CrossRef]

60. Weiffenbach, J.M.; Fox, P.C.; Baum, B.J. Taste and salivary function. Proc. Natl. Acad. Sci. USA 1986, 83, 6103-6106. [CrossRef] [PubMed]

61. Yeh, C.K.; Johnson, D.A.; Dodds, M.W.J. Impact of aging on human salivary gland function: A community-based study. Aging Clin. Exp. Res. 1998, 10, 421-428. [CrossRef] [PubMed]

62. Parker, B.A.; Chapman, I.M. Food intake and ageing-the role of the gut. Mech. Ageing Dev. 2004, 125, 859-866. [CrossRef] [PubMed] 
63. Davis, M.A.; Randall, E.; Forthofer, R.N.; Lee, E.S.; Margen, S. Living arrangements and dietary patterns of older adults in the United States. J. Gerontol. 1985, 40, 434-442. [CrossRef]

64. Hughes, G.; Bennett, J.M.; Hetherington, M. Old and alone: Barriers to healthy eating in older men living on their own. Appetite 2004, 43, 269-276. [CrossRef]

65. Ferris, A.M.; Duffy, V.B. Effect of olfactory deficits on nutritional status: Does age predict persons at risk? Ann. N. Y. Acad. Sci. 1989, 561, 113-123. [CrossRef]

66. Stevens, J.C.; Cain, W.S.; Demarque, A.; Ruthruff, A.M. On the discrimination of missing ingredients: Aging and salt flavour. Appetite 1991, 16, 129-140. [CrossRef]

67. Vasan, R.S.; Beiser, A.; Seshadri, S.; Larson, M.G.; Kannel, W.B.; D’Agostino, R.B.; Levy, D. Residual lifetime risk for developing hypertension in middle-aged women and men: The Framingham Heart Study. JAMA 2002, 287, 1003-1010. [CrossRef]

68. Manley, C.H. Psychophysiological effect of odor. Crit. Rev. Food Sci. Nutr. 1993, 33, 57-62. [CrossRef]

69. Goddaer, J.; Abraham, I.L. Effects of relaxing music on agitation during meals among nursing home residents with severe cognitive impairment. Arch. Psychiatr. Nurs. 1994, 8, 150-158. [CrossRef]

70. West, G.E.; Ouellet, D.; Oullette, S. Resident and staff ratings of foodservices in long-term care: Implications for autonomy and quality of life. J. Appl. Gerontol. 2003, 22, 57-75. [CrossRef]

71. Amarya, S.; Singh, K.; Sabharwal, M. Changes during aging and their association with malnutrition. J. Clin. Gerontol. Geriatr. 2015, 6, 78-84. [CrossRef]

72. Rudman, D.; Feller, A.G. Protein-caloric malnutrition in the nursing home. J. Am. Geriatr. Soc. 1989, 37, 173-183. [CrossRef]

73. Spence, C. Hospital food. Flavour 2017, 6, 3. [CrossRef]

74. Wang, S.Y. Weight loss and metabolic changes in dementia. J. Nutr. Health Aging 2002, 6, 201-205. [PubMed]

75. Coulston, A.M. Nutrition management in nursing homes. In Geriatric Nutrition, 2nd ed.; Morley, J.E., Glick, Z., Rubenstein, L.Z., Eds.; Raven Press: New York, NY, USA, 1995; pp. 295-302.

76. Dory, M. Enhancing the dining experience in long-term care. J. Nutr. Elder. 2004, 23, 99-109. [CrossRef] [PubMed]

77. Pearson, A.; Hocking, S.; Mott, S.; Riggs, A. Quality of care in nursing homes: From the resident's perspective. J. Adv. Nurs. 1993, 18, 20-24. [CrossRef] [PubMed]

78. Patel, B. 2020 Giving Elderly Patients an Extra Meal a Day Can Halve Their Chances of Dying in Hospital, NHS Study Finds. Daily Mail Online, 13 January 2019. Available online: https:/ /www.dailymail.co.uk/news/article-6586215/Giving-elderlypatients-extra-meal-day-halve-chances-dying-hospital.html (accessed on 1 December 2020).

79. Spence, C. Gastrophysics: The New Science of Eating; Viking Penguin: London, UK, 2017.

80. Reith, A.J.M.; Spence, C. The mystery of "metal mouth" in chemotherapy. Chem. Senses 2020, 45, 73-84. [CrossRef] [PubMed]

81. U.S. Cancer Statistics Working Group. US Cancer Statistics: 1999-2009 Incidence and Mortality Web-Based Report; USDHHS, CDC: Atlanta, GA, USA, 2013. Available online: www.cdc.gov/uscs (accessed on 1 December 2020).

82. White, M.C.; Holman, D.M.; Boehm, J.E.; Peipins, L.A.; Grossman, M.; Henley, S.J. Age and cancer risk: A potentially modifiable relationship. Am. J. Prev. Med. 2014, 46 (Suppl. 1), S7-S15. [CrossRef]

83. Koskinen, S.; Kälviäinen, N.; Tuorila, H. Perception of chemosensory stimuli and related responses to flavored yogurts in the young and elderly. Food Qual. Prefer. 2003, 14, 623-635. [CrossRef]

84. Koskinen, S.; Kälviäinen, N.; Tuorila, H. Flavor enhancement as a tool for increasing pleasantness and intake of a snack product among the elderly. Appetite 2003, 41, 87-96. [CrossRef]

85. Stevens, J.C.; Plantinga, A.; Cain, W.S. Reduction of odor and nasal pungency associated with aging. Neurobiol. Aging 1982, 3, 125-132. [CrossRef]

86. Forde, C.G.; Cantau, B.; Delahunty, C.M.; Elsner, R.J.F. Interactions between texture and trigeminal stimulus in a liquid food system: Effects on elderly consumers' preferences. J. Nutr. Health Aging 2002, 6, 130-133. [PubMed]

87. Boesveldt, S.; Bobowski, N.; McCrickerd, K.; Maître, I.; Sulmont-Rossé, C.; Forde, C.G. The changing role of the senses in food choice and food intake across the lifespan. Food Qual. Prefer. 2018, 68, 80-89. [CrossRef]

88. Spence, C. Eating with our ears: Assessing the importance of the sounds of consumption to our perception and enjoyment of multisensory flavour experiences. Flavour 2015, 4, 3. [CrossRef]

89. Spence, C.; Hobkinson, C.; Gallace, A.; Piqueras-Fiszman, B. A touch of gastronomy. Flavour 2013, 2, 14. [CrossRef]

90. Deliza, R.; MacFie, H.J.H. The generation of sensory expectation by external cues and its effect on sensory perception and hedonic ratings: A review. J. Sens. Stud. 1997, 2, 103-128. [CrossRef]

91. Piqueras-Fiszman, B.; Spence, C. Sensory expectations based on product-extrinsic food cues: An interdisciplinary review of the empirical evidence and theoretical accounts. Food Qual. Prefer. 2015, 40, 165-179. [CrossRef]

92. Piqueras-Fiszman, B.; Spence, C. Sensory incongruity in the food and beverage sector: Art, science, and commercialization. Petits Propos Culin. 2012, 95, 74-118. 
93. Schifferstein, H.N.J. Effects of product beliefs on product perception and liking. In Food, People and Society: A European Perspective of Consumers' Food Choices; Frewer, L., Risvik, E., Schifferstein, H., Eds.; Springer Verlag: Berlin, Germany, 2001; pp. 73-96.

94. Nanay, B. Multimodal mental imagery. Cortex 2018, 105, 125-134. [CrossRef]

95. Spence, C.; Deroy, O. Crossmodal mental imagery. In Multisensory Imagery: Theory and Applications; Lacey, S., Lawson, R., Eds.; Springer: New York, NY, USA, 2013; pp. 157-183.

96. Bonnell, M. Add color, crunch, and flavor to meals with fresh produce. 2. Hospitals 1966, 40, 126-130. [PubMed]

97. Spence, C. Background colour \& its impact on food perception \& behaviour. Food Qual. Prefer. 2018, 68, 156-166.

98. Adams, S. How to Rescue NHS Food? Put It on a Blue Plate: Simple Switch Has Helped Elderly and Weak Patients Eat Nearly a Third More. Available online: http:/ / www.dailymail.co.uk/news/article-2520058/How-rescue-NHS-food-Put-blue-plateSimple-switch-helped-elderly-weak-patients-eat-nearly-more.html (accessed on 1 December 2020).

99. Dunne, T.E.; Neargarder, S.A.; Cipolloni, P.B.; Cronin-Golomb, A. Visual contrast enhances food and liquid intake in advanced Alzheimer's disease. Clin. Nutr. 2004, 23, 533-538. [CrossRef] [PubMed]

100. Robbins, R. Can High-Tech Plates and Silverware Help Patients Manage Disease? Stat News, 28 December 2015. Available online: http:/ / www.statnews.com/2015/12/28/plates-silverware-health/(accessed on 1 December 2020).

101. Akyol, A.; Ayaz, A.; Inan-Eroglu, E.; Cetin, C.; Samur, G. Impact of three different plate colours on short-term satiety and energy intake: A randomized controlled trial. Nutr. J. 2018, 17, 46. [CrossRef] [PubMed]

102. Hannan-Jones, M.; Capra, S. Impact of type, size and shape of plates on hospital patients' perceptions of the quality of meals and satisfaction with foodservices. Appetite 2018, 120, 523-526. [CrossRef]

103. Navarro, D.A.; Boaz, M.; Krause, I.; Elis, A.; Chernov, K.; Giabra, M. Improved meal presentation increases food intake and decreases readmission rate in hospitalized patients. Clin. Nutr. 2016, 35, 1153-1158. [CrossRef]

104. Laguna, L.; Hetherington, M.M.; Chen, J.; Artigas, G.; Sarkar, A. Measuring eating capability, liking and difficulty perception of older adults: A textural consideration. Food Qual. Prefer. 2016, 53, 47-56. [CrossRef]

105. Van Stockkom, V.L.; Blok, A.E.; van Kooten, O.; de Graaf, C.; Stieger, M. The role of smell, taste, flavour and texture cues in the identification of vegetables. Appetite 2018, 121, 69-76. [CrossRef]

106. Schiffman, S.S. Food recognition in the elderly. J. Gerontol. 1977, 32, 586-592. [CrossRef]

107. Endo, H.; Ino, S.; Fujisaki, W. The effect of a crunchy pseudo-chewing sound on perceived texture of softened foods. Physiol. Behav. 2016, 167, 324-331. [CrossRef]

108. Endo, H.; Ino, S.; Fujisaki, W. Texture-dependent effects of pseudo-chewing sound on perceived food texture and evoked feelings in response to nursing care foods. Appetite 2017, 116, 493-501. [CrossRef] [PubMed]

109. Ferreira, M.P.N.; Previdelli, ÁN.; de Freitas, T.I.; Marques, K.M.; Goulart, R.M.M.; de Aquino, R.C. Dietary patterns and associated factors among the elderly. Rev. Bras. Geriatr. Gerontol. (Rio De Jan.) 2017, 20, 534-544. [CrossRef]

110. Spence, C.; Navarra, J.; Youssef, J. Using ice-cream as an effective vehicle for energy/nutrient delivery in the elderly. Int. J. Gastron. Food Sci. 2019, 16, 100140. [CrossRef]

111. Hyde, R.J.; Witherly, S.A. Dynamic contrast: A sensory contribution to palatability. Appetite 1993, 21, 1-16. [CrossRef]

112. Eccles, R.; Du-Plessis, L.; Dommels, Y.; Wilkinson, J.E. Cold pleasure. Why we like ice drinks, ice-lollies and ice cream. Appetite 2013, 71, 357-360. [CrossRef]

113. Gopnik, A. Sweet Revolution. The New Yorker, 3 January 2011. Available online: http:/ /www.newyorker.com/reporting/2011/0 1/03/110103fa_fact_gopnik(accessed on 1 December 2020).

114. Kitchen Theory. Available online: https:/ / kitchen-theory.com/ (accessed on 1 December 2020).

115. Hurley, J. The 'revolting food fad that passed its taste test. The Times, 15 January 2019; p. 43.

116. Anon. Good taste: Chefs have devised recipes for people who have lost the appreciation of food. The Times, 29 March 2019 ; p. 33.

117. Keeley, G. Chefs help sick to recover a sense of taste. The Times, 29 March 2019; p. 35.

118. Spence, C.; Piqueras-Fiszman, B. The Perfect Meal: The Multisensory Science of Food and Dining; Wiley-Blackwell: Oxford, UK, 2014.

119. Spence, C.; Youssef, J. Assessing the long-term impact of the molecular gastronomy movement on haute cuisine. Int. J. Gastron. Food Sci. 2018, 14, 35-44. [CrossRef]

120. Martin, L. Trend on Trial: Savoury Ice-Cream. Available online: https://recipes.sainsburys.co.uk/articles/fun-stuff/trend-ontrial-savoury-ice-cream (accessed on 1 December 2020).

121. Campbell-Schmitt, 18th Century Parmesan Ice Cream (Yes, The Cheese). Food \& Wine, 23 June 2017. Available online: https: //www.foodandwine.com/fwx/food/parmesan-cheese-ice-cream(accessed on 1 December 2020).

122. Marshall, A.B. Mrs A. B. Marshall's Cookery Book; Robert Hayes: London, UK, 1888.

123. Akesowan, A. Influence of soy protein isolate on physical and sensory properties of ice cream. Thai J. Agric. Sci. 2009, 1, 1-6.

124. Dervisoglu, M.; Yazici, F.; Aydemir, O. The effect of soy protein concentrate on the physical, chemical and sensory properties of strawberry flavored ice cream. Eur. Food Res. Technol. 2005, 221, 466-470. [CrossRef]

125. Ledda, E.; Dossena, A. Making Ice-Cream More Nutritious with Meat Left-Overs; PROSPARE (PROgress in Saving Proteins and Recovering Energy): Parma, Italy, 2011.

126. Patel, M.R.; Baer, R.J.; Acharya, M.R. Increasing the protein content of ice cream. J. Dairy Sci. 2006, 89, 1400-1406. [CrossRef]

127. Costa, F.F.; Resende, J.V.; Abreu, L.R.; Goff, H.D. Effect of calcium chloride addition on ice cream structure and quality. J. Dairy Sci. 2008, 91, 2165-2174. [CrossRef] 
128. Farouk, M.M.; Yoo, M.J.Y.; Hamid, N.S.A.; Staincliffe, M.; Davies, B.; Knowles., S.O. Novel meat-enriched foods for older consumers. Food Res. Int. 2018, 104, 134-142. [CrossRef] [PubMed]

129. Casas, F.; León, C.; Jovell, E.; Gómez, J.; Corvitto, A.; Blanco, R. Adapted ice cream as a nutritional supplement in cancer patients: Impact on quality of life and nutritional status. Clin. Transl. Oncol. 2012, 14, 66-72. [CrossRef] [PubMed]

130. Yeomans, M.; Chambers, L.; Blumenthal, H.; Blake, A. The role of expectancy in sensory and hedonic evaluation: The case of smoked salmon ice-cream. Food Qual. Prefer. 2008, 19, 565-573. [CrossRef]

131. Scheide, J. Flavour and medium: Mutual effects and interrelationship. Ice Cream Frozen Confect. 1976, $228-230$.

132. Kantono, K.; Hamid, N.; Shepherd, D.; Yoo, M.J.Y.; Grazioli, G.; Carr, T. Listening to music can influence hedonic and sensory perceptions of gelati. Appetite 2016, 100, 244-255. [CrossRef]

133. Kantono, K.; Hamid, N.; Shepherd, D.; Hsuan, Y.; Lin, T.; Brard, C.; Grazioli, G.; Carr, B.T. The effect of music on gelato perception in different eating contexts. Food Res. Int. 2018, 113, 43-56. [CrossRef]

134. Lin, Y.H.T.; Hamid, N.; Shepherd, D.; Kantono, K.; Spence, C. Background sounds influence the multisensory perception of chocolate gelati. Foods 2019, 8, 124. [CrossRef]

135. Xu, Y.; Hamid, N.; Shepherd, D.; Kantono, K.; Reay, S.; Martinez, G.; Spence, C. Background soundscapes influence the perception of ice-cream and on electrophysiological measures. Food Res. Int. 2019, 125, 108564. [CrossRef]

136. Xu, Y.; Hamid, N.; Shepherd, D.; Kantono, K.; Spence, C. Changes in flavour, emotion and electrophysiological measurements when chocolate ice cream is consumed in different eating environments. Food Qual. Prefer. 2019, 77, 191-205. [CrossRef]

137. Kitchen Theory. Available online: https:/ / kitchen-theory.com/portfolio-item/denville-hall/ (accessed on 1 December 2020).

138. Courtright, P.; Johnson, S.; Baumgartner, M.; Jordan, M.; Webster, J. Dinner music: Does it affect the behavior of psychiatric patients? J. Psychosoc. Nurs. Ment. Health Serv. 1990, 28, 37-40.

139. Davies, A.; Snaith, P. Mealtime problems in a continuing-care hospital for the elderly. Age Ageing 1980, 9, 100-105. [CrossRef] [PubMed]

140. Ragneskog, H.; Bråne, G.; Karlsson, I.; Kihlgren, M. Influence of dinner music on food intake and symptoms common in dementia. Scand. J. Caring Sci. 1996, 10, 11-17. [CrossRef] [PubMed]

141. Palmer, H. Sea Gulls ... Music for Rest and Relaxation; (Tape \#AR504); Education Activities, Inc.: Freeport, NY, USA, 1978.

142. Sandman, P.; Norberg, A.; Adolfsson, A.; Eriksson, S.; Nystrom, P. Prevalence and characteristics of persons with dependency on feeding at institutions for the elderly. Scand. J. Caring Sci. 1990, 4, 121-127. [CrossRef] [PubMed]

143. Rozin, P.; Dow, S.; Moscovitch, M.; Rajaram, S. What causes humans to begin and end a meal? A role for memory for what has been eaten as evidenced by a study of multiple meal eating in amnesic patients. Psychol. Sci. 1998, 9, 392-396. [CrossRef]

144. Wylie, C. Health and social factors affecting the food choices and nutritional intake of elderly people with restricted mobility. $J$. Hum. Nutr. Diet. 2000, 13, 363-371. [CrossRef]

145. Zoon, H.F.; DeGraaf, C.; Boesveldt, S. Food odours direct specific appetite. Foods 2016, 5, 12. [CrossRef]

146. Gollub, E.A.; Weddle, D.O. Improvements in nutritional intake and quality of life among frail homebound older adults receiving home-delivered breakfast and lunch. J. Am. Diet. Assoc. 2004, 104, 1227-1235. [CrossRef]

147. Schiffman, S.; Pasternak, M. Decreased discrimination of food odors in the elderly. J. Gerontol. 1979, 34, 73-79. [CrossRef]

148. Franklin-Wallis, O. Lizzie Ostrom Wants to Transform People's Lives through Their Noses. Wired, 3 October 2015. Available online: http:/ / www.wired.co.uk/magazine/archive/2015/11/play/lizzie-ostrom-smell(accessed on 1 December 2020).

149. Gardiner, S. Could Our Housewares Keep Us Healthier? Some Designers Are Harnessing Sound, Color, Smell and Touch in Products That Promote Well-Being and Independence for all. The Smithsonian Magazine, 3 May 2018. Available online: https:/ / www.smithsonianmag.com/smithsonian-institution/could-our-housewares-keep-us-healthier-180968950/(accessed on 1 December 2020).

150. Spence, C. Multisensory flavour perception. Cell 2015, 161, 24-35. [CrossRef]

151. Cerella, J. Information-processing rates in the elderly. Psychol. Bull. 1985, 98, 67-83. [CrossRef]

152. Cerella, J.; Hale, S. The rise and fall in information processing rates over the life span. Acta Psychol. 1994, 86, 109-197. [CrossRef]

153. Cabeza, R. Cognitive neuroscience of aging: Contributions of functional neuroimaging. Scand. J. Psychol. 2001, 42, 277-286. [CrossRef]

154. Laurienti, P.J.; Burdette, J.H.; Maldjian, J.A.; Wallace, M.T. Enhanced multisensory integration in older adults. Neurobiol. Aging 2006, 27, 1155-1163. [CrossRef]

155. Cabeza, R.; Anderson, N.D.; Locantore, J.K.; McIntosh, A.R. Aging gracefully: Compensatory brain activity in high-performing older adults. Neuroimage 2002, 17, 1394-1402. [CrossRef]

156. Freiherr, J.; Lundström, J.N.; Habel, U.; Reetz, K. Multisensory integration mechanisms during aging. Front. Hum. Neurosci. 2013, 7, 863. [CrossRef]

157. Laurienti, P.J.; Hugenschmidt, C.E. Multisensory processes in old age. In Multisensory Development; Bremner, A., Lewkowicz, D., Spence, C., Eds.; Oxford University Press: Oxford, UK, 2012; pp. 251-270.

158. Zhang, S.; Xu, W.; Zhu, Y.; Tian, E.; Kong, W. Impaired multisensory integration predisposes the elderly people to fall: A systematic review. Front. Neurosci. 2020, 14, 411. [CrossRef]

159. Spence, C. Extending the study of visual selective attention to a multisensory world. Atten. Percept. Psychophys. 2020. [CrossRef]

160. Spence, C. On the psychological impact of food colour. Flavour 2015, 4, 21. [CrossRef] 
161. Spence, C.; Levitan, C.; Shankar, M.U.; Zampini, M. Does food color influence taste and flavor perception in humans? Chemosens. Percept. 2010, 3, 68-84. [CrossRef]

162. Hisano, A. Visualizing Taste: How Business Changed the Look of What You Eat; Harvard University Press: Harvard, MA, USA, 2019.

163. Murray, M.M.; Eardley, A.F.; Edginton, T.; Oyekan, R.; Smyth, E.; Matusz, P.J. Sensory dominance and multisensory integration as screening tools in aging. Sci. Rep. 2018, 8, 1-11. [CrossRef]

164. Paakki, M.; Aaltojärvi, I.; Sandell, M.; Hopia, A. The importance of the visual aesthetics of colours in food at a workday lunch. Int. J. Gastron. Food Sci. 2019, 16, 100131. [CrossRef]

165. Paakki, M.; Sandell, M.; Hopia, A. Visual attractiveness depends on colorfulness and color contrasts in mixed salads. Food Qual. Prefer. 2019, 76, 81-90. [CrossRef]

166. Spence, C. Oral referral: On the mislocalization of odours to the mouth. Food Qual. Prefer. 2016, 50, 117-128. [CrossRef]

167. Stevenson, R.J.; Mahmut, M.K.; Oaten, M.J. The role of attention in the localization of odors to the mouth. Atten. Percept. Psychophys. 2011, 73, 247-258. [CrossRef]

168. Veldhuizen, M.G.; Small, D.M. Modality-specific neural effects of selective attention to taste and odor. Chem. Senses 2011, 36, 747-760. [CrossRef]

169. Spence, C. Attending to the chemical senses. Multisens. Res. 2019, 32, 635-664. [CrossRef]

170. Van der Wal, R.C.; van Dillen, L.F. Leaving a flat taste in your mouth: Task load reduces taste perception. Psychol. Sci. 2013, 24, 1277-1284. [CrossRef]

171. Forster, S.; Spence, C. "What smell?" Temporarily loading visual attention induces a prolonged loss of olfactory awareness. Psychol. Sci. 2018, 29, 1642-1652. [CrossRef]

172. Braude, L.; Stevenson, R.J. Watching television while eating increases energy intake. Examining the mechanisms in female participants. Appetite 2014, 76, 9-16. [CrossRef]

173. Tani, Y.; Kondo, N.; Takagi, D.; Saito, M.; Hikichi, H.; Ojima, T. Combined effects of eating alone and living alone on unhealthy dietary behaviors, obesity and underweight in older Japanese adults: Results of the JAGES. Appetite 2015, 95, 1-8. [CrossRef]

174. Hurst, G. Eating meals alone is biggest lifestyle cause of unhappiness. The Times, 22 May 2018; p. 15.

175. Tani, Y.; Sasaki, Y.; Haseda, M.; Kondo, K.; Kondo, N. Eating alone and depression in older men and women by cohabitation status: The JAGES longitudinal survey. Age Ageing 2015, 44, 1019-1026. [CrossRef]

176. Spence, C.; Mancini, M.; Huisman, G. Digital commensality: On the pros and cons of eating and drinking with technology. Front. Psychol. 2019, 10, 2252. [CrossRef] [PubMed]

177. Busse, E.W. Eating in late life: Physiological and psychological factors. Am. Pharm. 1980, 20, 36-38. [CrossRef]

178. Thomas, N.; Emond, R. Living alone but eating together: Exploring lunch clubs as a dining out experience. Appetite 2017, 119, 34-40. [CrossRef] [PubMed]

179. Singh, S. The Soon to Be $\$ 200 B$ online Food Delivery Is Rapidly Changing the Global Food Industry. Forbes, 9 September 2019. Available online: https://www.forbes.com/sites/sarwantsingh/2019/09/09/the-soon-to-be-200b-online-food-delivery-israpidly-changing-the-global-food-industry/?sh=1a257cb1bcb9(accessed on 1 December 2020).

180. Ellson, A. Food Goes to Waste as More of Us Dine Alone. The Times, 1 July 2015. Available online: http:/ /www.thetimes.co.uk/ tto/money/consumeraffairs/article4484213.ece(accessed on 1 December 2020).

181. White, W. Tesco Targets Singletons Eating alone with Smaller Portions. Daily Mail Online, 7 July 2018. Available online: https: / / www.dailymail.co.uk/news/article-5928507/Tesco-targets-singletons-eating-smaller-portions-shrunk-bottles-wine. html(accessed on 1 December 2020).

182. Sekuler, R.; Blake, R. Sensory underload. Psychol. Today 1987, 12, 48-51.

183. Murphy, C.; Cain, W.S.; Hegsted, D.M. Research prospects in nutrition and the chemical senses in aging. Ann. N. Y. Acad. Sci. 1989, 561, 333-338. [CrossRef]

184. Sulmont-Rossé, C.; Symoneaux, R.; Feyen, V.; Maître, I. Improving Food Sensory Quality with and for Elderly Consumers. In Methods in Consumer Research Volume 2: Alternative Approaches and Special Applications; Ares, G., Tomasco, P.A.V., Eds.; Elsevier: Amsterdam, The Netherlands, 2018; Available online: https://hal.inrae.fr/hal-02791415 (accessed on 1 December 2020).

185. Haigh, R. The aging process: A challenge for design. Appl. Erg. 1993, 24, 9-14. [CrossRef]

186. Pirkl, J.J. Transgenerational Design; Products for an Aging Population; Van Nastrand Reinhold: New York, NY, USA, $1994 ;$ pp. 41-51.

187. Doets, E.L.; Kremer, S. The silver sensory experience-A review of senior consumers' food perception, liking and intake. Food Qual. Prefer. 2016, 48, 316-332. [CrossRef]

188. Special Report the Silver Dollar. The Economist, 14 August 2018. Available online: https://www.economist.com/special-report/ 2018/08/14/the-silver-dollar(accessed on 1 December 2020).

189. Moschis, G.P. Marketing to older adults: An updated overview of present knowledge and practice. J. Consum. Mark. 2003, 20, 516-525. [CrossRef]

190. Dermiki, M.; Prescott, J.; Sargent, L.J.; Willway, J.; Gosney, M.A.; Methven, L. Novel flavours paired with glutamate condition increased intake in older adults in the absence of changes in liking. Appetite 2015, 90, 108-113. [CrossRef]

191. Harrison, S. Many COVID-19 Patients Lost Their Sense of Smell. Will They Get It Back? Available online: https://www. nationalgeographic.com/science/2020/08/thousands-covid-19-patients-lost-sense-smell-will-get-back-cvd/ (accessed on 1 December 2020). 
192. Navarra, J.; Ruiz-Ceamanos, A.; Moreno, J.J.; García-Basterrechea, J.M.; Haro-Licer, J.; de Sinnett, S. Acute nasal dryness in COVID-19. PLOS ONE 2020. submitted.

193. Parma, V.; Ohla, K.; Veldhuizen, M.G.; Niv, M.Y.; Kelly, C.E.; Bakke, A.J. More than smell-COVID-19 is associated with severe impairment of smell, taste, and chemesthesis. Chem. Senses 2020, 45, 609-622. [CrossRef]

194. Sutherland, S. Mysteries of COVID Smell Loss Finally Yield Some Answers. Scientific American, 18 November 2020. Available online: https:/ / www.scientificamerican.com/article/mysteries-of-covid-smell-loss-finally-yield-some-answers1/(accessed on 1 December 2020). 